\title{
Conceptions of Human Resource Management and Training in SMEs of Eastern Macedonia and Thrace
}

\author{
Charis Vlados ${ }^{1,2}$, Dimos Chatzinikolaou ${ }^{1}$, Theodore Koutroukis ${ }^{1}$, Angelika Kokkinaki ${ }^{2} \&$ Ioanna Tsarpa $^{1}$ \\ ${ }^{1}$ Department of Economics, Democritus University of Thrace, Komotini, Greece \\ ${ }^{2}$ School of Business, University of Nicosia, Nicosia, Cyprus \\ Correspondence: Dimos Chatzinikolaou, Department of Economics, Democritus University of Thrace, Komotini, \\ 69100, Greece. Tel: 30-25-3103-9824. E-mail: dimchatz@econ.duth.gr
}

Received: November 1, 2020

Accepted: December 1, 2020

Online Published: December 10, 2020

doi:10.5430/jms.v11n4p21

URL: https://doi.org/10.5430/jms.v11n4p21

\begin{abstract}
Human resource management and continuing training are prerequisites for business innovation, especially when the fourth industrial revolution causes the rapid emergence of knowledge-intensive professions and the constraint of older ones. This article examines how human resources, in-business training, and educational needs are significant parts of entrepreneurial innovation and business development. We present field research that we conducted in the business ecosystem of Eastern Macedonia and Thrace, which is a less competitive region of Greece and Europe. After examining the region's economic profile, we continue with field research results in its retail sector. Our findings suggest that these businesses desire and search for more systematic actions towards training enhancement and human resource management upgrading. Thus, we propose a policy mechanism that could function as a "business clinic" for the region, including the diagnosis of needs and "therapeutic" intervention in terms of education and knowledge. This local development policy could create a growth spiral for the entire socio-economic spatialized system.
\end{abstract}

Keywords: human resource management, professional training, business education, Eastern Macedonia and Thrace, retail firms, Institutes of Local Development and Innovation, fourth industrial revolution

\section{Introduction and Structure}

According to contemporary scholarly literature, business innovation requires the development of sophisticated human resource management structures and continuing training and education (Khan et al., 2011; Machado, 2018). This study examines one case of firms' internal processes in a less developed business ecosystem and how they address the interconnection between developing their human resources and training, either in-business training or general education provided by the State.

Although the literature recognizes the significance of the connection between human resource management, training, and education, the study tends limits itself in large corporations' frameworks, which have a more adequate and better organized operational structure. The present analysis proves how less competitive firms, and, by extension, local business ecosystems face comparative weaknesses that derive from their human resources lack of knowledge and operational aptitudes. Concerning the specific less developed business ecosystems, the literature does not focus systematically on sophisticated management techniques that, if applied in SMEs, seem to lead to overall competitiveness enhancement.

Our approach tries to investigate the operation of the dipole "human resource management - education" from the perspective of small and medium-sized entrepreneurship in less developed regions. Along this path, it combines the relative underdevelopment study with the insufficient micro-competitiveness, which is a symptom of peripheral local business ecosystems.

The article is structured as follows to achieve these goals:

- Section 2 will explore the concept of human resource management and the dimension of modern enterprises' training and educational needs.

- Section 3 will present the Greek region of Eastern Macedonia and Thrace through recent data, focusing on 
the retail sector from which we derived responses from a sample of firms.

- Section 4 will present the method, identity, and findings of field research in these retail businesses about the interrelation between human resources and training.

- Finally, Section 5 will conclude and discuss policy implications.

\section{Human Resources, Training, and Education}

Nowadays, an increasing number of companies recognize the growing importance of managing and developing human resources in achieving their long-term goals. The recognition of human resources as an asset of crucial importance means that an effective Human Resource Management (HRM) policy can create the base for a sustainable competitive advantage and thereby the long-term company's high performance (Beardwell et al., 2003; Cohen \& Veled-Hecht, 2010).

HRM corresponds to the efficient use of human capital that is a prerequisite for achieving organizational goals and enhancing organizational adaptability and productivity (Al-Qudah et al., 2020; Akunda et al., 2018; Olannye et al., 2017). Human resources development plays a crucial role in adding value to organizations and contributing to corporate strategy (Mathis \& Jackson, 2011). Moreover, it becomes increasingly apparent in our days that a firm's workforce is an asset, as employee behavior, productivity, and creativity are central to the overall achievement of business objectives (Senyucel, 2009).

The fundamental functions of human resource management can be the following (Tyson, 2006):

I. Planning and recruiting: Candidate selection is a process of gathering information and evaluating candidates to select the most suitable for specific jobs. With this process, the company selects the best-suited persons from the candidates' list to the job position criteria, considering the current environmental conditions. Choosing human resources is a crucial procedure for the company because of the severe consequences that wrong recruitment decisions can have.

II. Training and development: Today's radical evolution of knowledge and technology necessitates employees' continuous development and learning, as learned skills are a precondition for competitiveness and efficiency. Systematic training of human resources leads to increased productivity, ability development, improved performance and contributes to organizational development. The firm should not consider the training program as an extra expense but as a productive investment that meets the organization's needs. Training can improve the skills that employees already have, and specific areas of improvement are the following:

* Knowledge: Improving the stock of observations, facts, and information related to the job.

- Skills: Develop and improve intellectual and interpersonal abilities to increase the employees' effectiveness, such as making proper decisions and handling problems.

* Attitudes: Change behavior to make employees more responsive to various environmental factors. Attitudes towards clients and colleagues, tolerance to cultural differences, self-confidence, and willingness to take responsibility are examples that a company might seek to develop with training.

- Competencies: A term that encompasses all the professional characteristics, knowledge, and abilities needed to perform a job successfully.

III. Control and performance measurement: HRM evaluation is a measure to control whether a member of the organization contributes to the predetermined goals. Assessment should be a system that is in line with the organization's culture in bringing the desired results, uniting and keeping all the pieces, taking further steps, defining measures, and empowering the participants (Hall, 2008). It involves the design and implementation of methods to assess the value of employees' work.

Of course, this HRM description with the systematic processes refers to entrepreneurship that does not correspond to all kinds of entrepreneurship and all the different business ecosystems' structural conditions. On the contrary, it is now clear in the literature that there are business models that survive and grow-especially in less developed business ecosystems - in which human resource management continues to have a sporadic and slightly systematic character (Vlados, 2012). Its design is usually elliptical, selection and staffing are based mostly on personal and idiosyncratic ties, training and education are occasional and discontinuous. At the same time, the performance audit does not follow systematic and standardized procedures.

Nevertheless, beyond these idiosyncrasies, all companies nowadays, regardless of size or physiology (Vlados, 2019b), need to operate and survive within an increasingly turbulent and uncertain environment. In these intense and 
pressing competitive conditions, employees need to build and assimilate new skills and be trained in new techniques. In practice, internal training is a fundamental element for organizational change, helping the business evolve and deal with the changing socio-economic environment since the new technological era of the fourth industrial revolution calls for higher knowledge capacity (Dunlap, 2015; Kelly, 2019). According to the analysis made by the World Economic Forum on the future of work (World Economic Forum, 2016), fostering organizational training is critical since workers show skill mismatches in specific jobs and industries. That is, their current skill sets cannot meet future requirements.

The use of modern technologies, the need for strategic originality, and the ever-intensified search for managerial competence in the fluctuant and continuously evolving international market and global socio-economic system create pressing needs for all organizations to acquire qualified staff (Vlados, 2019a). It becomes understood in this direction that human resource education is necessary to keep high performance. Therefore, modern businesses invest large sums of money in their employees' training and education to keep sales of their goods and services high and renew their customer base, especially now when the online commerce sector is growing immensely (Dhamija, 2012). Organizations also might be successful in the future by offering lifelong education and learning. Studies show that most millennials in these large corporations will be intrapreneurs since they will behave as entrepreneurs even though they do not participate in the enterprise's ownership (Eberhard et al., 2017).

Therefore, human resources development is central to firms' strategic, technological, and managerial ability. Also, employees' educational level, which depends on public secondary and tertiary education structures, continuing vocational training and technical education, contributes to enhancing organizational innovation and change management capabilities (Porto Gómez et al., 2018). In scholarly literature, this link between HRM, education, and training is clear:

* "Quality employee training and development leads to an improvement in employee performance, which in turn leads to an improvement in the services offered to clients and greater organizational profits" (Mpofu \& Hlatywayo, 2015, p. 136).

* "Recovery from the crisis can occur relatively quickly if there is sufficient margin of stability of the economy and understanding of the strategic importance of education for the development of a country. It is necessary to make the process of education and professional training more and more effective as well as to seek new possibilities of enhancing its quality" (Kováčová et al., 2018, p. 65).

* "The existence of well-designed education and training policies improves the skills of HR and often allows them [the business staff] to develop new ones that they did not have before" (Stavrinoudis \& Psimoulis, 2017, p. 185).

The definitions above show the need to examine the nature and the requisites for constructing a successful education or training program. To this end, the literature standards can function as a benchmark for the less developed firms in organizational systematization terms (Stapenhurst, 2009). To this end, how the firms of a less developed business ecosystem apply and absorb these priorities? How do small businesses perceive the development necessity of their human resources? How do they understand general education as a critical part of this procedure? Finally, what is their overall understanding of training? After analyzing, in Section 3, the profile of the region in which we conducted field research, Section 4 will present the relevant findings to these questions from a sample of retail sector firms in this region.

\section{The Region of Eastern Macedonia and Thrace (REMTh): The Retail Sector and Vocational Training in the Greek Economy}

The Region of Eastern Macedonia and Thrace (REMTh) is one of Greece's thirteen regions and is a less developed geographical area, both in Greece and Europe. REMTh is a border region on the north-east borderline of the country and, as a result, it combines socio-economic and demographic problems that cause underdevelopment (Prokkola, 2019; Varol \& Soylemez, 2019). It is a border region that ranks among those regions experiencing negative economies of scale, increased living costs for the residents, and low added value for businesses (Arieli, 2019; Boden, 2017).

Specifically, REMTh hosts about 5.5\% of Greece's total population in its five regional units (Eurostat, 2020c). According to Eurostat's latest data $(2020 \mathrm{~h})$, the purchasing power standard per inhabitant at current market prices increased in REMTh by $6.57 \%$ between 2012 and 2018 (13,700 to 14,600). In Greece and EU28 recorded an increase of $10.47 \%$ (19,100 to 21,100$)$ and $16.1 \%$ (26,700 to 31,000$)$, respectively. This lesser increase in purchasing power shows that despite a general increase in the financial ability to buy products and services in Europe, REMTh 
faces structural weaknesses stemming from its firms' income. We see a similar trend in the growth rate of value-added in the region, which is negative from 2009 to 2015, and only in 2016 has started to show positive values (Table 1).

Table 1. The real growth rate of regional gross value added. Percentage change on the previous year (Eurostat, 2020e)

\begin{tabular}{llllllllll}
\hline & $\mathbf{2 0 0 9}$ & $\mathbf{2 0 1 0}$ & $\mathbf{2 0 1 1}$ & $\mathbf{2 0 1 2}$ & $\mathbf{2 0 1 3}$ & $\mathbf{2 0 1 4}$ & $\mathbf{2 0 1 5}$ & $\mathbf{2 0 1 6}$ & $\mathbf{2 0 1 7}$ \\
\hline REMTh & -3 & -0.9 & -11.4 & -5.2 & -4.8 & -0.4 & -1.1 & 0.4 & 0.6 \\
\hline
\end{tabular}

Another indicative statistic of the region's socio-economic system is the number of people aged 18-24 who receive neither formal education nor training. Between 2012 and 2018 (Eurostat, 2020d), this index decreased by 3.5\% in the EU28 (17.2 to 13.7 ), $8.1 \%$ in Greece (28.1 to 20 ), and $11.6 \%$ in REMTh (35.6 to 24). These data show a chronic comparative hysteresis, despite the significant downward trend of the index, as a substantial number of young people is absent from productive activities. Concerning the tertiary educational attainment for the age class 25-64 in the region, this increased from $17 \%$ to $25.1 \%$ during the years 2007-2018 (Eurostat, 2020a), which shows that more people are gaining access to higher education structures. This breakthrough is likely to take a considerable amount of time to deliver increased added value. To this end, a significant percentage of Greek firms do not offer continuing vocational training, something indicative of their sophistication level (Table 2).

Table 2. Percentage of continuing vocational training (CVT) courses by the size of the enterprise (Eurostat, 2020b)

\begin{tabular}{lccc}
\hline \multicolumn{2}{l}{$\mathbf{2 0 0 5}$} & $\mathbf{2 0 1 0}$ & $\mathbf{2 0 1 5}$ \\
\hline Having a specific person or unit responsible for organizing CVT or having a training plan or budget including \\
CVT & & & \\
EU-28 (2013-2020) & 35.6 & 45.3 & 47.0 \\
Greece & 10.3 & 16.4 & 15.3 \\
\hline 250 persons employed or more & & & \\
EU-28 (2013-2020) & 90.9 & 93.1 & 65.3 \\
Greece & 70.4 & 82.8 & 68.2 \\
\hline From 50 to 249 persons employed & & & \\
EU-28 (2013-2020) & 78.0 & 80.3 & 40.2 \\
Greece & 38.6 & 45.5 & \\
\hline From 10 to 49 persons employed & & & 69.3 \\
EU-28 (2013-2020) & 54.9 & 62.1 & 18.6 \\
Greece & 16.0 & 24.2 & \\
\hline
\end{tabular}

Table 3 shows that Greece's position in offering continuing vocational training within the enterprise is significantly lower than the European average for all business sizes. The smaller businesses that employ 10 to 49 persons show the most considerable divergence in continuing vocational training courses since, in 2015, only $18.6 \%$ compared to $69.3 \%$ across Europe offer such education and training activities. Finally, for the retail firms' part, these recorded between 2013 and 2017 significant variations in their rates of growth (Table 3).

Table 3. Retail trade, except motor vehicles and motorcycles (Eurostat, 2020g)

\begin{tabular}{llllll}
\hline \multicolumn{2}{c}{$\mathbf{2 0 1 3}$} & $\mathbf{2 0 1 4}$ & $\mathbf{2 0 1 5}$ & $\mathbf{2 0 1 6}$ & $\mathbf{2 0 1 7}$ \\
\hline Local units - number & & & & \\
Greece & 181,719 & 199,855 & 194,051 & 180,122 & 166,971 \\
REMTh & 11,545 & 11,177 & 10,705 & 9,912 & 9,407 \\
\hline
\end{tabular}

Wages and Salaries - million euro 


\begin{tabular}{|c|c|c|c|c|c|}
\hline Greece & $2,488.7$ & $2,494.8$ & $2,537.8$ & $2,970.2$ & $2,716.0$ \\
\hline REMTh & 92.6 & 87.7 & 75.5 & 90.3 & 83.2 \\
\hline \multicolumn{6}{|c|}{ Persons employed - number } \\
\hline Greece & 415,154 & 429,169 & 377,549 & 426,411 & 411,672 \\
\hline REMTh & 24,433 & 20,978 & 17,111 & 19,262 & 18,181 \\
\hline \multicolumn{6}{|c|}{ Employment's growth rate percentage } \\
\hline Greece & -4.2 & 3.4 & -12.4 & 12.9 & -3.5 \\
\hline REMTh & : & -14.1 & -35.0 & 12.6 & -5.6 \\
\hline
\end{tabular}

Their most significant decline is in 2015, marked by a period of general socio-political turmoil and worsening of the Greek crisis (Vlados, 2018). From 2016 onwards, the situation seems to be moving towards relative stabilization. The growth rates of employment, wages, and salaries in absolute terms have increased to return at a lower downward trend in 2017 , for both the country and the region.

Table 4. Employment in thousands (Eurostat, 2020f)

\begin{tabular}{llllll}
\hline & $\mathbf{2 0 1 3}$ & $\mathbf{2 0 1 4}$ & $\mathbf{2 0 1 5}$ & $\mathbf{2 0 1 6}$ & $\mathbf{2 0 1 7}$ \\
\hline Greece & $3,459.00$ & $3,479.50$ & $3,548.00$ & $3,610.30$ & $3,682.70$ \\
\hline REMTh & 183.6 & 189.7 & 194.1 & 196.1 & 200.9 \\
\hline
\end{tabular}

Overall, the region's economy is experiencing significant and chronic developmental lagging. Compared to the European average rates, REMTh is still a less developed and competitive regional economic formation, despite a marked improvement in specific aspects. The retail sector, which employs about one in ten employees in Greece and REMTh (Table 4), appears to be in a contraction phase.

Concerning the structural background of the business environment of the region, Vlados et al. (2018) find that, although most firms operate in the service industry, only the primary sector presents specialization and multiplier effects. In the field of qualitative characteristics of REMTh's business ecosystem, Vlados, Chatzinikolaou et al. (2019) present the findings of field surveys conducted in the region and arrive at the following conclusions:

i. REMTh, like the rest of the country, is facing comparative business underdevelopment that derives from the specific "physiology" of the firms. These firms tend to articulate an "instinctive" and superficial strategy, sporadic and superficial technology choices, and management based mostly on the everyday practice experience that lacks systematization. This type of business "physiology" does not allow them to innovate sufficiently and manage change effectively.

ii. The sum of the idiomorphic environmental dimensions (internal and external) makes most locally operating firms in the region show significant deficits of competitiveness and business adaptability in terms of global competition.

iii. A significant percentage of small firms in this business ecosystem shows a willingness to systematize their strategy, technology, and management conceptions and practices, which requires a chronic "therapy" capable of driving the entire regional business ecosystem in a trajectory of its competitiveness enhancement.

The next section presents field research on a sample of these firms in the region, focusing on the dimensions of human resource development, training, and educational needs.

\section{Field Research in the Retail Sector of REMTh}

\subsection{Methodology}

At the end of 2019, we conducted mixed research (qualitative and quantitative) with the parallel use of open and graded questionnaires (see Appendix A). We chose the method because we tried to investigate the meanings and insights for the subject under consideration in qualitative terms primarily (Levitt et al., 2017). We collected the data through purposive sampling, Likert-type questions, and open-ended interviews (Dudwick, 2006; Gopaldas, 2016). 
This qualitative research takes place in a natural setting and allows us to create an actual detail level that results from the involvement in the field experience (Creswell, 2014). A qualitative study's data are descriptive since they derive from the participant's words, conceptions, comprehensions, and expressions. The qualitative part of the research focuses on the respondents' understanding and day-to-day experiences and, therefore, tries to understand the same aspect from multiple conceptual perspectives.

In line with grounded theory principles, which is a form of qualitative research (Corbin \& Strauss, 2015; Walia, 2015), we tried to uncover new findings grounded in the data rather than assessing an existing theory empirically. The grounded theory researchers base the findings on emergence, which means they are not aware from the beginning about the issue at hand, which is in line with our method. We did not know how these respondents act and think from the beginning (Mohajan, 2018). Other elements of the grounded theory that we use in this study are the following: first, we build theoretically relevant constructs that support the sampling; second, we venture on a comparative approach; third, we give meaning to the useful information based on "theoretical sensitivity" by trying to interpret the results as "spherically" as possible (Hancock et al., 2009). However, we cannot describe our study as a purely grounded theory since our questionnaires were pre-prepared. We were also not altering and reorganizing the research questions during the interview.

Specifically, the questionnaire included a Likert scale of questions from 1 to 5: 1 corresponded to "Not important," 2 to "Slightly important," 3 to "Moderately important," 4 to "Important," 5 to "Very important." These had two chronological ranges: the "my today's appreciation" and the "how I appreciated five years ago" range. The scale we used is psychometric because the respondents specify the extent to which they agree or disagree with a series of statements, which is, in fact, a method that can capture the intensity of their feelings, comprehensions and evaluation for a given situation (Batterton \& Hale, 2017; Harpe, 2015). In trying to distribute the negative and positive answers through the wording evenly, we appreciated that the average values could show the trend to each of the issues.

The other category of questions that we built additionally were open-ended questions for answers of up to one hundred words by the respondents. We applied this practice to compare the answers with information we already know and develop a new theoretical perspective on the issue. This diagnosis method enables the respondent to offer in-depth information about the subject under analysis (Worley, 2015).

In conclusion, our method was to collect data through interviews based on a pre-defined questionnaire distributed via in-person meetings. This approach's advantages are that we could see these firms' behavior and that our participants offered historical information. The limitation of this method is that it only offers indirect information filtered through the interviewers' views. Second, the researcher's presence may bias responses in the direction of "beautifying" the situation and presenting a different picture than the actual. Finally, all raw data are available upon request.

\subsection{Identity of the Research Field}

We collected data with purposive sampling, a non-probability sampling method where our research members judge and select the sample elements. We estimated that by approaching the retail businesses in the region, we could have a sufficiently large homogeneous sample of firms facing perceptual and practical difficulties in developing their human resources (Black, 2010). 


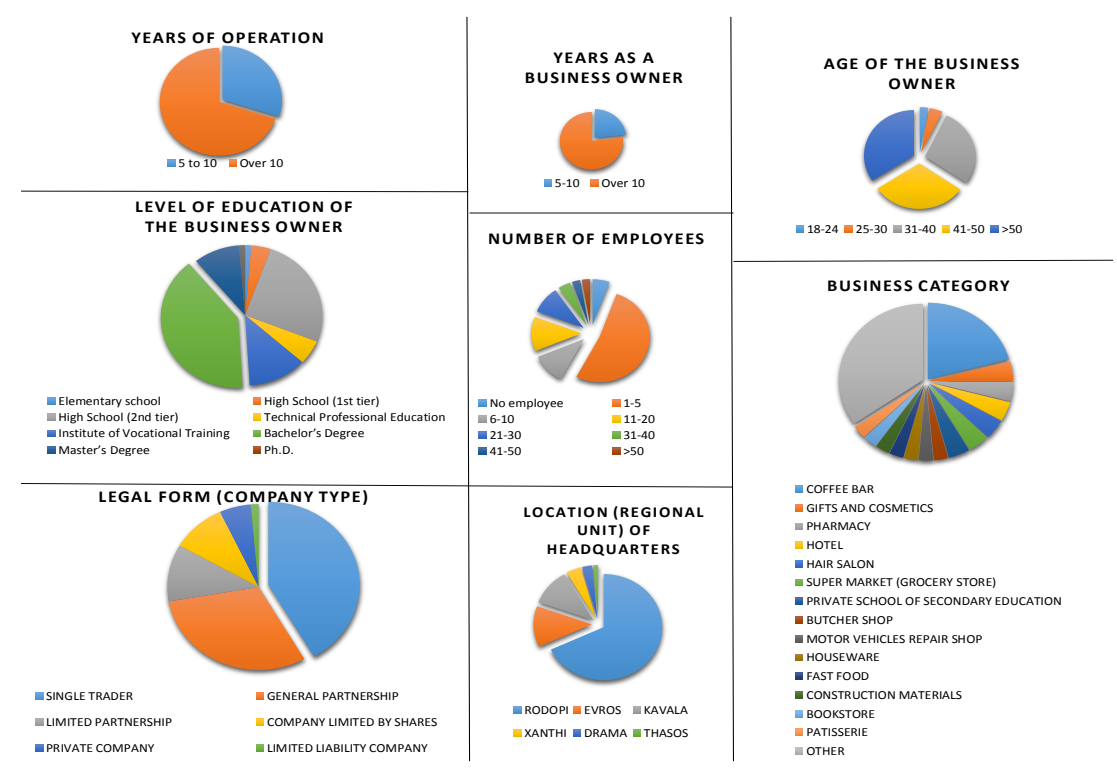

Figure 1. Identity of field research

Specifically, the sample is eighty-four questionnaires, of which we singled out seventy-two for which we received valid data and complete answers to all questions. These seventy-two cases have the following characteristics (Figure 1):

- Most firms operate for more than ten years, while the business owners have been entrepreneurs for more than ten years.

- The business owners belong mostly to the age group of over fifty, while a significantly smaller proportion is between 25 and 30 years of age.

- Most participants have a bachelor's degree, followed by those with a high school diploma.

- Most firms employ one to five people, something that classifies them as "micro" enterprises.

- As "micro" enterprises, their legal form is "single trader" mostly. The general partnership, a form in Greece common in small businesses with two partners, is the next in line company type.

- Most firms are in REMTh's regional capital, Rodopi.

- Finally, most firms belong in the "other" and coffee bars category.

\subsection{Findings}

The first set of questions concerned the human resources dimension. In the first Likert-type question to what extent age, experience, education, and gender are essential characteristics of business performance, the answers are, on average, "Important" (4), except for the gender that is close to "Moderately important" (3). This trend shows that the respondents understand - also based on the question's wording - the value of well-trained human resources, where gender is not a significant parameter. Overall, we see a minimal average increase today compared to five years ago (Figure 2). 


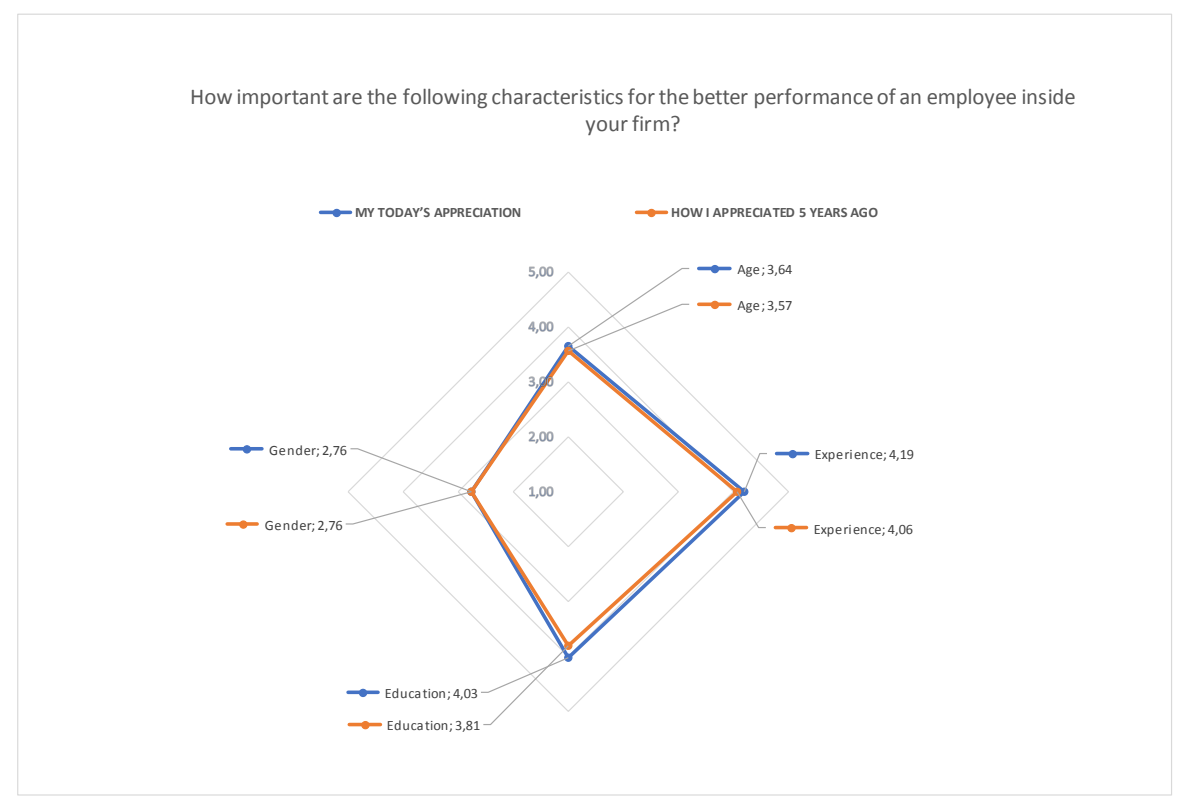

Figure 2. First human resources question

To the second Likert-type question, that is, to what extent high wage cost, insufficient specialization, work inexperience, and overall negative working culture are difficulties in terms of human resources development for the firm, the answers follow a similar pattern (Figure 3). All are close to "Important" (4) today, except the past relative importance of high wage cost and insufficient specialization that lie in the range of "Moderately important" (3). This tendency appears probably because these respondents want better-skilled people in their business, although they also fear potential increases to the cost incurred. This "fear" occurs perhaps because the Greek business environment is still comparatively less competitive (World Bank, 2019). A form of idiosyncratic and less "technocratic" entrepreneurship still prevails in the Greek business environment. This less competitive entrepreneurship has favored (and favored by) clientelistic mixes of economic policy, which incubated a chronic structural crisis (Andrikopoulos \& Nastopoulos, 2015; Vlados, 2017).

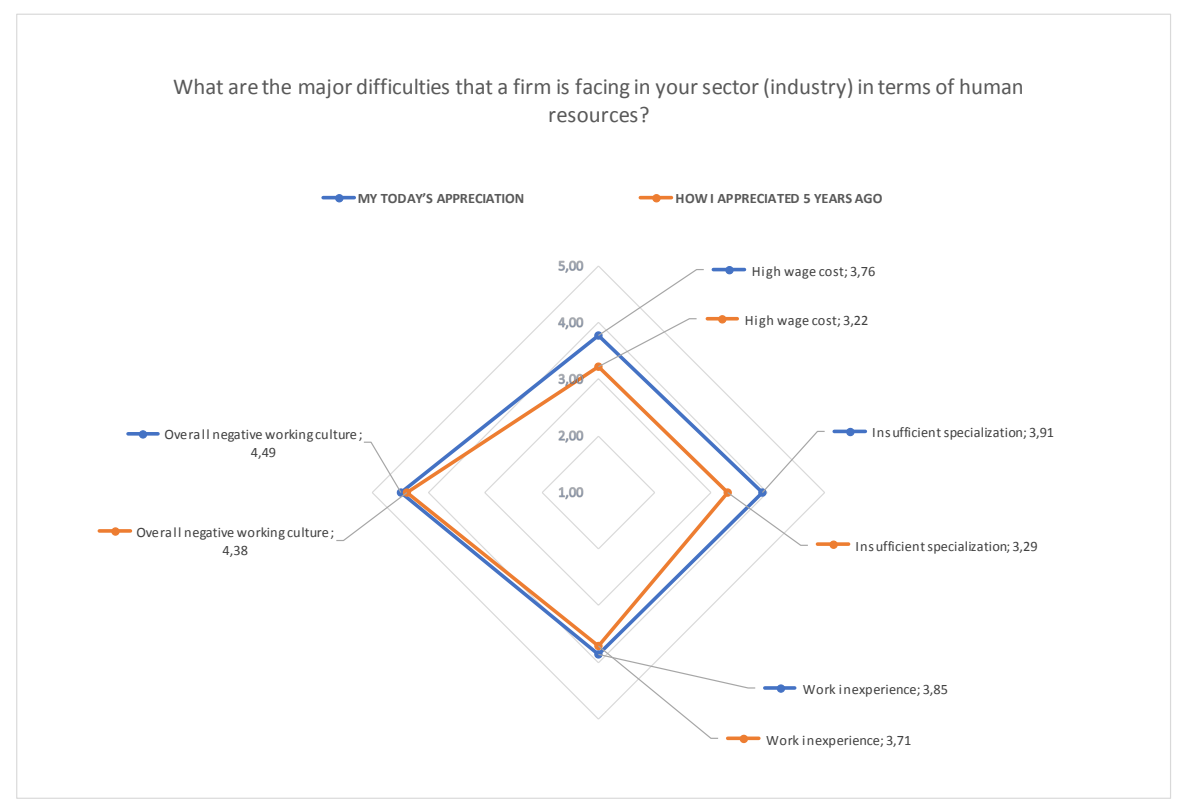

Figure 3. Second human resources question 
The first set of questions was closing with the open-ended question, "What reasons do you think made you change your views over the last five years concerning the human resources you employ? In other words, what do you think are the new conditions and challenges for your business that contributed to changing your earlier understanding, and why?"

We understand that the psychometric scale's high results do not fit exactly how these firms perform their daily practice from the answers we received. We often find in the answers that nothing has changed in the last five years. Others focus on the economic crisis and rising costs: indicatively, as one respondent said, "We do not have the same easiness as before to give opportunities to unskilled or inexperienced people."

Few answers also focus on having a degree as a human resources selection criterion. Quite often, respondents reported an increase in competition in their sector, which drives them to seek personnel with working experience. Therefore, we rarely see the need to reposition the business strategy and human resource management to improve employees' knowledge, skills, attitudes, and competencies.

Only a minority of responses point in this direction. For example, one respondent said that "training and experience of human resources play a strategic role" while another said, "an inexperienced worker can be trained in the subject according to the business requirements."

Then, the second set of questions concerned the category of training and education. To the first question (Figure 4), that is, to what extent the respondent would like the company to have more sophisticated technical training, adequate and "fuller" general education, on-the-job training, and significant work experience, the answers are by average also near "Important" (4), both for today and the past. Therefore, the high scoring pattern continues, which shows these respondents' ambition and willingness to acquire more knowledge and systematic training methods.

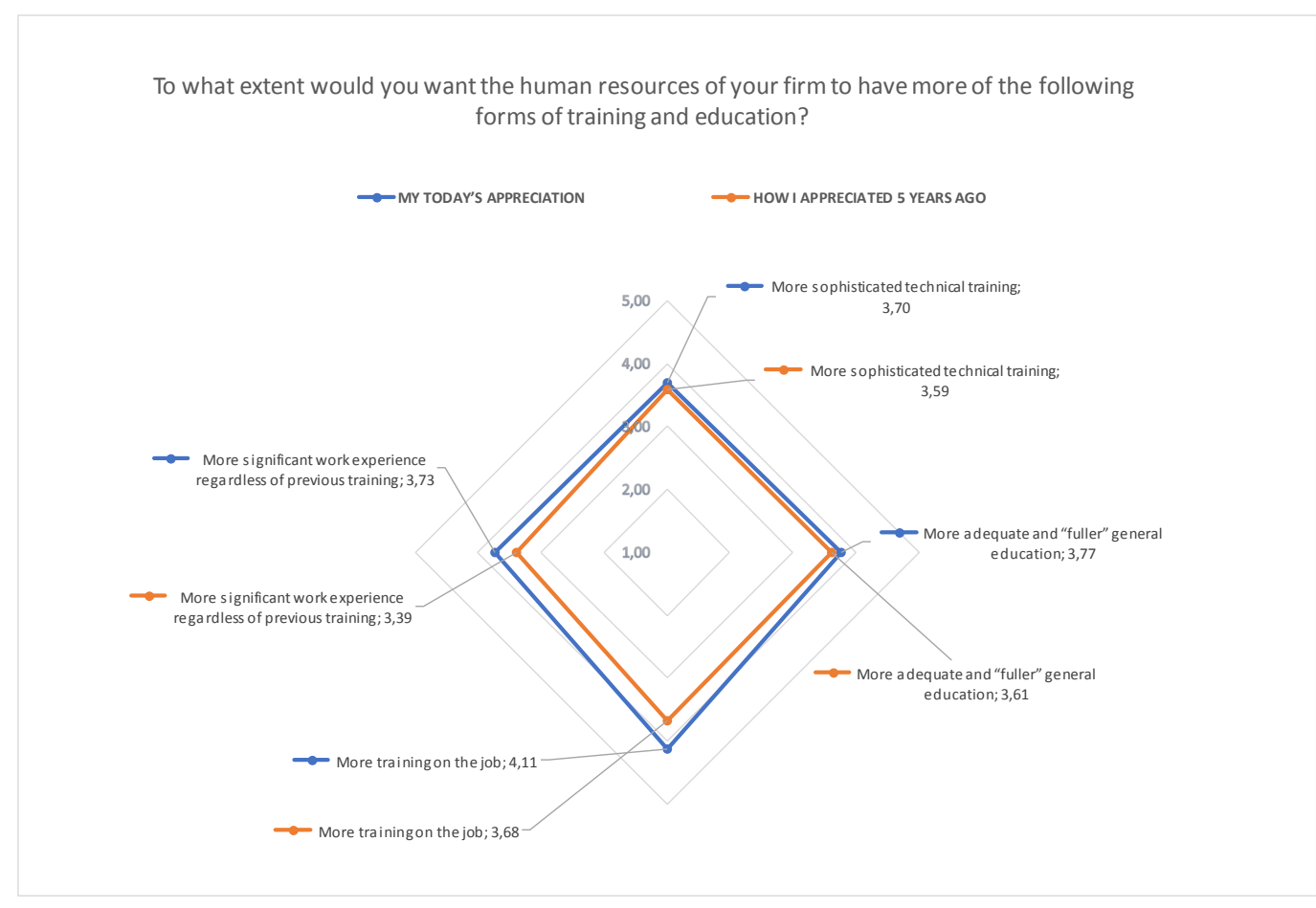

Figure 4. First training/education question

The last question, which concerned the extent to which it would be interesting for the respondent to expand their knowledge, high scores appeared again (Figure 5). The respondents gave a rating near "Very important" (5) to the interest in developing business planning methods. This score is probably because this concept seems more "familiar" and more "easily realizable" than management techniques, sales techniques, and customer care. 


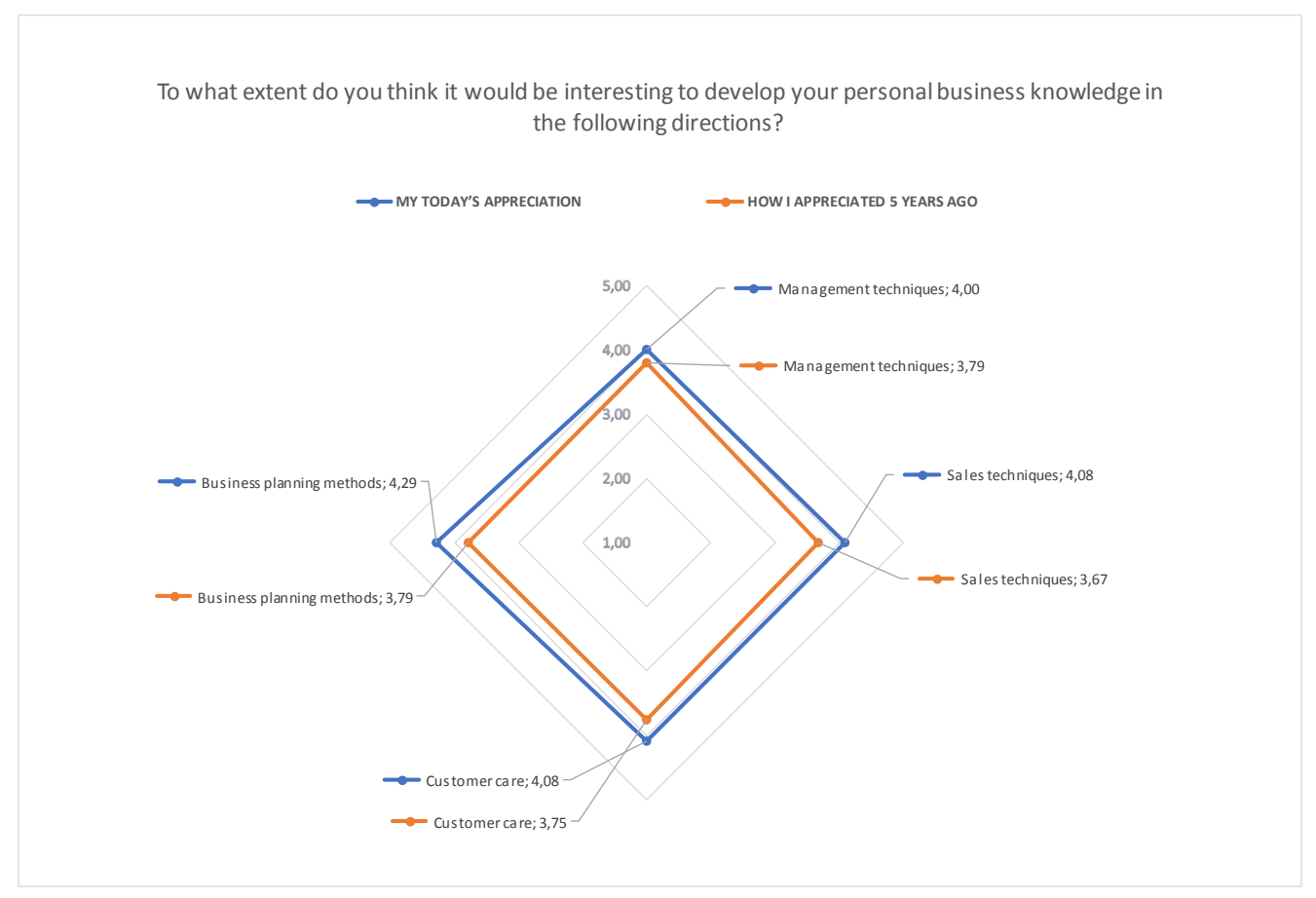

Figure 5. Second training/education question

The second set of questions was closing with the open-ended question, "Have you changed your perception during the past five years about the importance of training your human resources?" We can distinguish three categories"poles" of answers to this question:

- First, there are those responses that follow a static understanding of reality, arguing that the business has not changed in the last five years, nor is it going to change. In this context, we also received responses assessing the dimension of education as relatively insignificant: for example, as one respondent argued, "We are a family business and, therefore, we do not pay much attention to education."

- Second, there is the category of responses that express a desire to improve this business area but do not include sufficient elements of the standards suggested by the international literature and practice, such as the development of an integrated training program. As one respondent answered, "work experience is an important part of evolution, which should be cultivated lifelong." While such a perspective is not wrong, it does not consider the dimension of lifelong education apart from experience.

- The third category justifies the tertiary education that most respondents have as they offer answers that approach an integrated perspective of in-business training. For example, the following responses seem quite eloquent:

- $\quad$ "As a graduate in Human Resource Management, I understand the importance of human resources education in all steps of the working lifetime."

- " "The employee must be able to upgrade himself or herself through education, expertise, and scientific training."

- "It is important to educate our people to increase the competitiveness of the business."

\section{Conclusions and Policy Implications}

This article explored the human resources and education conceptual dimension by studying Eastern Macedonia and Thrace's less developed Greek region. We conducted field research in a sample of the region's retail trade firms, a sector that employs about $10 \%$ of the total workforce in Greece and REMTh. We concluded that, although there is an elevated level of general education in Greece and along the region, these local firms show a relative insufficiency to implementing innovative actions and create sustainable competitive advantages by applying systematic training and human resource management methods. The region's small retail businesses are mostly in a phase of transition:

1. First, most firms perceive their reality quasi- statically and, unavoidably, face a relative inability to 
recognize the critical role of systematic human resource management and education in practical terms, and, because of this, they face a reproducible lack of competitiveness.

2. Second, most firms seem to strive increasingly for systematization in this area, where short-term "successes" are likely to occur. Sporadic and "spontaneous" technological choices, intuitive strategic plans, and relative adherence to traditional practice in the sphere of management might lead to such short-term success.

3. Finally, a small minority of firms in the region seem capable of systematically approaching and implementing modern theory and practice standards in this field.

Overall, this research offers a new image of the region and the specific sector that complements our findings from other relevant studies. These earlier studies have come to the following conclusions:

A. The firms of the Eastern Macedonia and Thrace region have, cross-sectorally, a narrow approach to innovation (Vlados \& Chatzinikolaou, 2019c), an inability to perceiving their innovation and change management as mechanisms of exiting their crisis (Vlados, Katimertzopoulos, et al., 2019), an insufficiency of conceiving their strategy according to the standards set by the strategic management literature (Vlados \& Chatzinikolaou, 2019d), and a low systematization in articulating their strategic, technological, and managerial potential (Vlados \& Chatzinikolaou, 2019a). All the above characteristics and dimensions express and co-create an environment of low competitiveness. To this end, the overall understanding of the significance of modern and systematic business education (internal and external to the business) might remain degraded and underutilized.

B. Most firms in Greece, cross-sectorally, seem to be also reproducing during the structural crisis of 2009-2019 their "monadocentric physiology" by facing increasing pressure in terms of their low competitiveness. According to Vlados (2004), monadocentric means that a firm is inflexible and attached to the "monad" (usually the face of the business owner) to schematize its strategic choices, technological alertness, and managerial capacity. This fact leads most Greek firms to perceive their strategy instinctively, their technology sporadically, and their management based on their practical experience (Vlados \& Chatzinikolaou, 2019b). In this context, it becomes clear why there are containments and obstacles for the further systematization of business training and education processes in all the Greek industries.

This fact allows us to revisit and enrich our proposal for the creation of the Institutes of Local Development and Innovation (ILDI) mechanism. According to Vlados (2016), a micro-meso level policy proposal for the region is the Institutes of Local Development and Innovation (ILDI). This policy proposal (Figure 6) aims to establish "business clinics" (Aro et al., 2013) that can diagnose these firms' level of strategy, technology, and management ("Stra.Tech.Man" approach). 


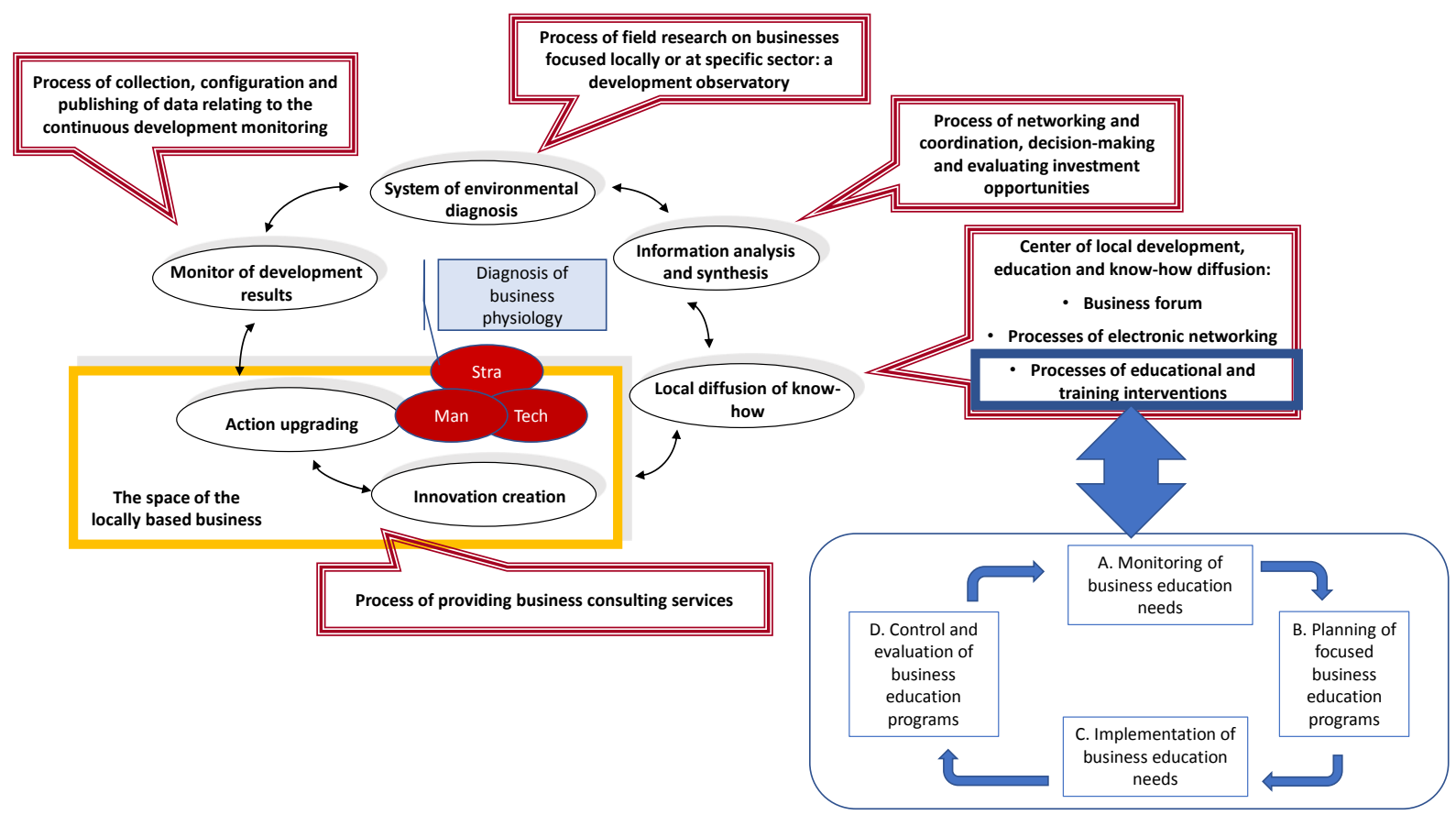

Figure 6. The policy proposal of the Institutes of Local Development and Innovation (ILDI), based on Vlados (2016)

We propose the mechanism of the ILDI for the region of Eastern Macedonia and Thrace and other Greek regional business ecosystems to connect all those institutions that can strengthen local entrepreneurship. These institutions are still relatively uncoordinated (Vlados \& Chatzinikolaou, 2019e). We propose this mechanism to follow six steps, which could initially start with diagnosing the skills and prospects of the local environment firms. It could then be collecting and synthesizing relevant information to offer feedback on investment opportunities to regional actors. Next, it could be disseminating this acquired expertise by finding out possibilities for educational interventions within the firms and the region. It could then be diagnosing the strengths and weaknesses of specific local firms, which could take part as "patients" that need counseling in terms of their strategic, technological, and managerial potential and adaptability. Finally, this ongoing cycle could be starting again by monitoring the occurred developmental results.

In conclusion, amidst the evolving global crisis and the restructuring of globalization (Vlados, Deniozos, et al., 2019), aggravated and accelerated by the current pandemic of COVID-19, the transition to a new phase of capitalism seems inevitable. The burgeoning fourth industrial revolution for which an increasing number of policymakers and scholars worldwide predicted it would create a gap between better and less-skilled workers creates an emergency nowadays. This fact creates new significant challenges for the less developed European regions and globally, like the one we focused on in this study.

The structural and transformational crisis of capitalism is not an unprecedented event in the world economy's evolution. Today's difference is the necessity to reinforce innovation, continuing training, and lifelong education, both within the enterprises and among the employed human resources, especially in the weakest and most vulnerable socio-economic formations. The need to strengthen remote and "immaterial" production and distance learning structures in the world's most developed countries and the pressing need for the restructuration of "traditional" occupations and industries in the less developed regions and nations are becoming central expressions within the current emergence of "new globalization."

This research showed that the firms of a less competitive business ecosystem desire to systematize education and human resource management. Furthermore, intervention at a micro-meso level should cultivate the respective strengthening mechanisms. A more in-depth version of this research could extend the method to other sectors, taking representative samples of firms and exploring how they behave within their specific locality or region. This way, it could investigate whether corresponding strengthening mechanisms can articulate interventions in other areas where there is a need to stimulate innovative potential, which goes through human resources' development dynamics. 


\section{Acknowledgments}

We would like to express our sincere gratitude to Dr. Andreas Andrikopoulos, who offered useful comments during this paper's writing.

\section{References}

Akunda, D., Chen, Z., \& Gikiri, S. N. (2018). Role of HRM in talent retention with evidence. Journal of Management and Strategy, 9(2), 8-19. https://doi.org/10.5430/jms.v9n2p8

Al-Qudah, S., Obeidat, A. M., \& Shrouf, H. (2020). The impact of strategic human resources planning on the organizational performance of public shareholding companies in Jordan. Problems and Perspectives in Management, 18(1), https://doi.org/10.21511/ppm.18(1).2020.19

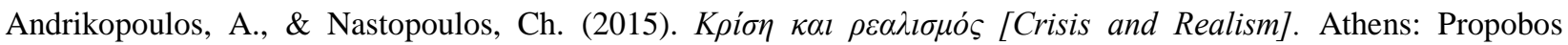
Publications.

Arieli, T. (2019). Intermunicipal cooperation and ethno-social disparity in peripheral regions. Regional Studies, 53(2), 183-194. https://doi.org/10.1080/00343404.2018.1453129

Aro, P., Heinonen, M., Parkkola, T., Vironmäki, E., Ahola, H., Iso-Aho, J., ... Vuorela, T. (2013). Co-Learning Service Design within the PALI Project. The 3rd Service Design and Service Innovation Conference, 8-10 February, Espoo, Finland, 1-7.

Batterton, K. A., \& Hale, K. N. (2017). The Likert scale what it is and how to use it. Phalanx, 50(2), 32-39.

Beardwell, I., Holden, L., \& Claydon, T. (2003). Human resource management: A contemporary approach. Harlow, UK: Financial Times Prentice Hall.

Black, K. (2010). Business statistics: Contemporary decision making (6th ed.). Hoboken, N.J: John Wiley \& Sons.

Boden, M. (2017). RIS3 Implementation in lagging regions: Lessons from Eastern Macedonia and Thrace. European Structural \& Investment Funds Journal, 5(1), 77-83.

Cohen, A., \& Veled-Hecht, A. (2010). The relationship between organizational socialization and commitment in the workplace among employees in long-term nursing care facilities. Personnel Review, 39(5), 537-556. https://doi.org/10.1108/00483481011064136

Corbin, J. M., \& Strauss, A. L. (2015). Basics of qualitative research: Techniques and procedures for developing grounded theory (4th ed.). Los Angeles, US: SAGE Publications.

Creswell, J. W. (2014). Research design: Qualitative, quantitative, and mixed methods approaches (4th ed.). Los Angeles, London, New Delhi, Singapore, Washington, DC: SAGE.

Dhamija, P. (2012). E-recruitment: A roadmap towards e- human resource management. Researchers World: International Refereed Social Sciences Journal, 3(2), 33-39.

Dudwick, N. (2006). Analyzing social capital in context: A guide to using qualitative methods and data. Washington, D.C.: World Bank Institute.

Dunlap, M. (2015). 5 keys to an effective training and development program. Journal of Financial Planning; Denver, 28(1), 20-21.

Eberhard, B., Podio, M., Alonso, A. P., Radovica, E., Avotina, L., Peiseniece, L., ... Solé-Pla, J. (2017). Smart work: The transformation of the labour market due to the fourth industrial revolution (I4.0). International Journal of Business \& Economic Sciences Applied Research, 10(3), 47-66. https://doi.org/10.25103/ijbesar.103.03

Eurostat. (2020a, January 31). Population aged 25-64 by educational attainment level, sex and NUTS 2 regions (\%). Database - Eurostat. Retrieved March, 2020, from https://ec.europa.eu/eurostat/web/regions/data/database

Eurostat. (2020b, February 24). Enterprises with CVT planning by type of planning, type of training provided and size class-\% of all enterprises. Database - Eurostat. Retrieved March, 2020, from https://ec.europa.eu/eurostat/web/education-and-training/data/database

Eurostat. (2020c, February 24). The population on 1 January by age group, sex, and NUTS 3 region. Database Eurostat. Retrieved March, 2020, from https://ec.europa.eu/eurostat/web/regions/data/database

Eurostat. (2020d, February 24). Young people neither in employment nor in education and training by sex and NUTS 2 regions. Database - $\quad$ Eurostat. Retrieved March, 2020, from https://ec.europa.eu/eurostat/web/regions/data/database 
Eurostat. (2020e, March 5). Real growth rate of regional gross value added (GVA) at basic prices by NUTS 2 regions-Percentage change on previous year. Database - Eurostat. Retrieved March, 2020, from https://ec.europa.eu/eurostat/web/regions/data/database

Eurostat. (2020f, March 6). Employment by sex, age and NUTS 2 regions. Database - Eurostat. Retrieved March, 2020, from https://ec.europa.eu/eurostat/web/regions/data/database

Eurostat. (2020g, March 9). SBS data by NUTS 2 regions and NACE Rev. 2 (from 2008 onwards). Database Eurostat. Retrieved March, 2020, from https://ec.europa.eu/eurostat/web/regions/data/database

Eurostat. (2020h, March 18). Gross domestic product (GDP) at current market prices by NUTS 2 regions. Database Eurostat. Retrieved March, 2020, from https://ec.europa.eu/eurostat/web/regions/data/database

Gopaldas, A. (2016). A front-to-back guide to writing a qualitative research article. Qualitative Market Research: An International Journal, 19(1), 115-121. https://doi.org/10.1108/QMR-08-2015-0074

Hall, B. W. (2008). The new human capital strategy: Improving the value of your most important investment-Year after year. New York: American Management Association.

Hancock, B., Ockleford, E., \& Windridge, K. (2009). An introduction to qualitative research. Nottingham, Sheffield, UK: National Institute for Health Research.

Harpe, S. E. (2015). How to analyze Likert and other rating scale data. Currents in Pharmacy Teaching and Learning, 7(6), 836-850. https://doi.org/10.1016/j.cpt1.2015.08.001

Kelly, R. (2019). Constructing leadership 4.0: Swarm leadership and the Fourth Industrial Revolution. Cham, Switzerland: Springer International Publishing. https://doi.org/10.1007/978-3-319-98062-1

Khan, R. A. G., Khan, F. A., \& Khan, D. M. A. (2011). Impact of training and development on organizational performance. Global Journal of Management and Business Research, 11(7), 62-68.

Kováčová, L., Kavan, Š., Mesároš, M., \& Lošonczi, P. (2018). Education and training of crisis management and civil protection workers in the Slovak republic. International Multidisciplinary Scientific GeoConference Surveying Geology and Mining Ecology Management, SGEM, 18(5\&4), 59-66. https://doi.org/10.5593/sgem2018/5.4/S22.008

Levitt, H. M., Motulsky, S. L., Wertz, F. J., Morrow, S. L., \& Ponterotto, J. G. (2017). Recommendations for designing and reviewing qualitative research in psychology: Promoting methodological integrity. Qualitative Psychology, 4(1), 2-22. https://doi.org/10.1037/qup0000082

Machado, C. (2018). Training and development of human resources: A brief contribution to a better understanding of its relevance. In C. Machado, \& J. P. Davim (Eds.), Organizational Behaviour and Human Resource Management: A Guide to a Specialized MBA Course (pp. 173-203). Cham, Switzerland: Springer International Publishing. https://doi.org/10.1007/978-3-319-66864-2_8

Mathis, R. L., \& Jackson, J. H. (2011). Human resource management. Mason, Ohio: South-Western Cengage Learning.

Mohajan, H. K. (2018). Qualitative research methodology in social sciences and related subjects. Journal of Economic Development, Environment and People, 7(1), 23-48. https://doi.org/10.26458/jedep.v7i1.571

Mpofu, M., \& Hlatywayo, C. K. (2015). Training and development as a tool for improving basic service delivery; The case of a selected municipality. Journal of Economics, Finance and Administrative Science, 20(39), 133-136. https://doi.org/10.1016/j.jefas.2015.10.004

Olannye, A. P., \& Okoro, O. M. (2017). Enhancing organizational performance through human resource outsourcing in the Nigerian deposit money banks. Journal of Management and Strategy, 8(4), 67-78. https://doi.org/10.5430/jms.v8n4p67

Porto Gómez, I., Zabala-Iturriagagoitia, J. M., \& Aguirre Larrakoetxea, U. (2018). Old wine in old bottles: The neglected role of vocational training centres in innovation. Vocations and Learning, 11(2), 205-221. https://doi.org/10.1007/s12186-017-9187-6

Prokkola, E.-K. (2019). Border-regional resilience in EU internal and external border areas in Finland. European Planning Studies, 27(8), 1587-1606. https://doi.org/10.1080/09654313.2019.1595531

Senyucel, Z. (2009). Managing the human resource in the 21 st century. Denmark: Ventus Publishing. 
Stapenhurst, T. (2009). The benchmarking book: A how-to-guide to best practice for managers and practitioners. Oxford, UK: Routledge.

Stavrinoudis, T., \& Psimoulis, M. (2017). How do education and training policies determine customer satisfaction and hotels' performance?. European Journal of Tourism Research, 17, 177-190.

Tyson, S. (2006). Essentials of human resource management. Burlington, UK: Elsevier. https://doi.org/10.1016/B978-0-7506-6795-1.50011-X

Varol, C., \& Soylemez, E. (2019). Socio-spatial network structures in border regions: West and east borders of Turkey. In X. Ye, \& X. Liu (Eds.), Cities as Spatial and Social Networks (pp. 207-225). Cham, Switzerland: Springer International Publishing. https://doi.org/10.1007/978-3-319-95351-9_12

Vlados, Ch. (2004). La dynamique du triangle stratégie, technologie et management: L'insertion des entreprises grecques dans la globalisation [Thèse de doctorat de Sciences Économiques, Université de Paris X-Nanterre]. Retrieved March, 2020, from http://www.theses.fr/2004PA100022

Vlados, Ch. (2012). The search of competitiveness and the entrepreneurial evolution in a global environment: Toward a new approach of development dynamics based on the case of Greek productive system. Journal of Management Sciences and Regional Development, 8, 91-116. https://doi.org/10.2139/ssrn.3218008

Vlados, Ch. (2016). Strategy of small and medium-sized enterprises in conditions of crisis: The Stra.Tech.Man

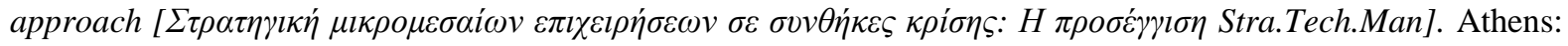
Kritiki Publications.

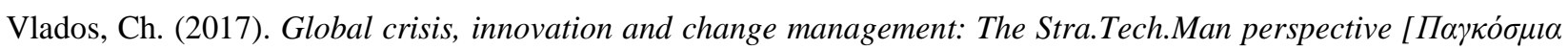

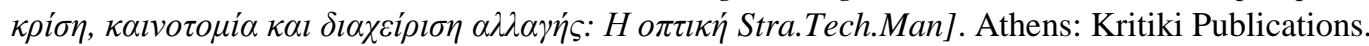

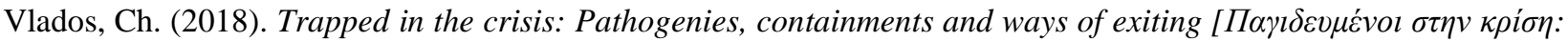

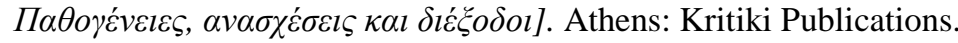

Vlados, Ch. (2019a). Stra.Tech.Man (strategy-technology-management): Theory and concepts. KSP Books. Retrieved March, 2020, from http://books.ksplibrary.org/978-605-7602-83-1/

Vlados, Ch. (2019b). Change management and innovation in the "living organization": The Stra.Tech.Man approach. Management Dynamics in the Knowledge Economy, 7(2), 229-256. https://doi.org/10.25019/MDKE/7.2.06

Vlados, Ch., \& Chatzinikolaou, D. (2019a). Business ecosystems policy in Stra.Tech.Man terms: The case of the Eastern Macedonia and Thrace region. Journal of Entrepreneurship, Management and Innovation, 15(3), 163-197. https://doi.org/10.7341/20191536

Vlados, Ch., \& Chatzinikolaou, D. (2019b). Crisis and entrepreneurship in Greece: Present, past and evolving trends. 6th International Conference on Applied Economics "Institutions \& the Knowledge Economy," Volos, Greece. Retrieved March, 2020, from https://www.researchgate.net/publication/333652675_Crisis_and_entrepreneurship_in_Greece_Present_past_an d_evolving_trends

Vlados, Ch., \& Chatzinikolaou, D. (2019c). The multiple perception of innovation: The case of micro and small enterprises in the region of Eastern Macedonia and Thrace. Journal of Entrepreneurship, Business and Economics, 7(1), 17-41.

Vlados, Ch., \& Chatzinikolaou, D. (2019d). Strategy perception and implementation on less developed business ecosystems micro and small enterprises: The service sector of Eastern Macedonia and Thrace. Business Management and Strategy, 10(2), 27-63. https://doi.org/10.5296/bms.v10i2.15008

Vlados, Ch., \& Chatzinikolaou, D. (2019e). Developments on helix theory: Exploring a micro-evolutionary repositioning in Stra.Tech.Man terms. International Journal of World Policy and Development Studies, 5(10), 87-99. https://doi.org/10.32861/ijwpds.510.87.99

Vlados, Ch., Chatzinikolaou, D., Katimertzopoulos, F., \& Koutroukis, T. (2019). Regional underdevelopment and less developed business ecosystems: The case of Eastern Macedonia and Thrace. Bulletin of Applied Economics, $6(2), 31-44$.

Vlados, Ch., Deniozos, N., \& Chatzinikolaou, D. (2018). Towards a new approach of local development under crisis conditions: Empowering the local business ecosystems in Greece, by adopting a new local development policy. International Journal of Regional Development, 5(1), 1-24. https://doi.org/10.5296/ijrd.v5i1.11955 
Vlados, Ch., Deniozos, N., \& Chatzinikolaou, D. (2019). Global crisis and restructuring: Theory, analysis, and the case of Greece. KSP Books. Retrieved March, 2020, from http://books.ksplibrary.org/978-605-7602-89-3/

Vlados, Ch., Katimertzopoulos, F., Chatzinikolaou, D., Deniozos, N., \& Koutroukis, T. (2019). Crisis, innovation and change management in less developed local business ecosystems: The case of Eastern Macedonia and Thrace. Perspectives of Innovations, Economics and Business, 19(2), 114-140.

Walia, R. (2015). A saga of qualitative research. Sociology and Criminology-Open Access, 3(2), 1-3. https://doi.org/10.4172/2375-4435.1000124

World Bank. (2019). Doing Business 2019: Training for reform. Washington, DC: World Bank.

World Economic Forum. (2016). The future of jobs employment, skills and workforce strategy for the Fourth Industrial Revolution. Geneva, Switzerland: World Economic Forum.

Worley, P. (2015). Open thinking, closed questioning: Two kinds of open and closed question. Journal of Philosophy in Schools, 2(2), 17-29. https://doi.org/10.21913/JPS.v2i2.1269

\section{Appendix A}

Human Resource Management, Training, and Educational Needs Questionnaire

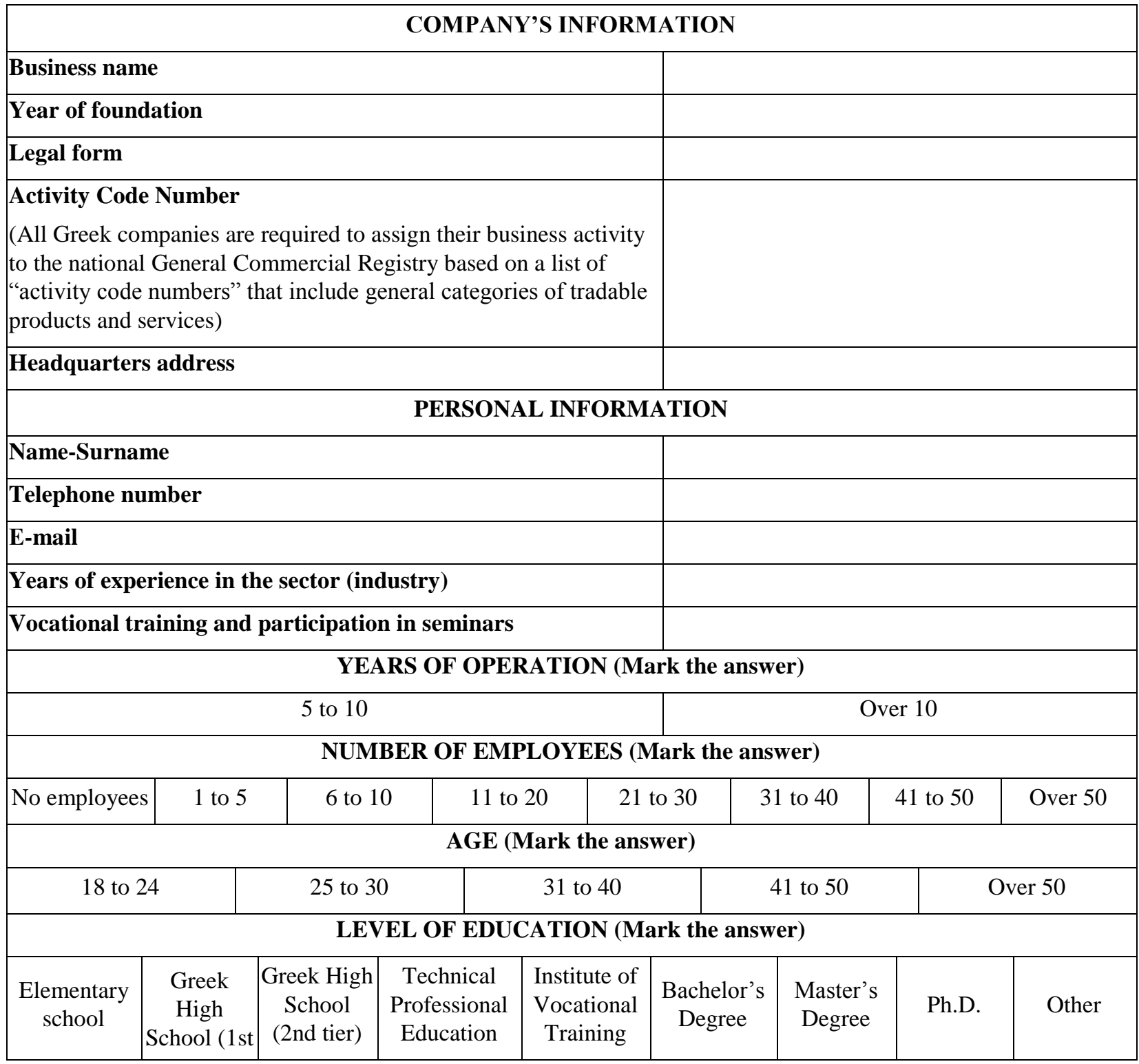




\begin{tabular}{|l|l|l|l|l|l|l|}
\hline & tier) & & & & \\
\hline \multicolumn{7}{|l|}{ YEARS AS A BUSINESS OWNER (Mark the answer) } \\
\hline
\end{tabular}

\section{A. Human Resources}

\section{How important are the following characteristics for the better performance of an employee inside your} firm?

\subsection{AGE}

My today's appreciation:

\begin{tabular}{|l|l|l|l|l|} 
1-Not important & 2-Slightly important & 3-Moderately important & 4-Important & 5-Very important
\end{tabular}

How I appreciated five years ago:

\begin{tabular}{|c|l|l|r|r|}
\hline 1-Not important & 2-Slightly important & 3-Moderately important & 4-Important & 5-Very important \\
\hline \multicolumn{5}{|c|}{ 1.2. EXPERIENCE } \\
\hline My today's appreciation: \\
\hline 1-Not important & 2-Slightly important & 3-Moderately important & 4-Important & 5-Very important \\
\hline How I appreciated five years ago: & 1.3. EDUCATION & 5-Very important \\
\hline 1-Not important & 2-Slightly important & 3-Moderately important & 4-Important \\
\hline \multicolumn{5}{|l|}{} \\
\hline My today's appreciation: \\
\hline 1-Not important & 2-Slightly important & 3-Moderately important & 4-Important & 5-Very important \\
\hline How I appreciated five years ago: & 2-Slightly important & 3-Moderately important & 4-Important & 5-Very important \\
\hline 1-Not important &
\end{tabular}

\subsection{GENDER}

My today's appreciation:

\begin{tabular}{|l|l|l|l|l|} 
1-Not important & 2-Slightly important & 3-Moderately important & 4-Important & 5-Very important \\
\hline
\end{tabular}
How I appreciated five years ago:

\begin{tabular}{|l|l|l|l|l|} 
1-Not important & 2-Slightly important & 3-Moderately important & 4-Important & 5-Very important
\end{tabular}

2. What are the major difficulties a firm faces in your sector (industry) in terms of human resources?

\subsection{HIGH WAGE COST}

My today's appreciation:

\begin{tabular}{|l|l|l|l|l|} 
1-Not important & 2-Slightly important & 3-Moderately important & 4-Important & 5-Very important
\end{tabular}

How I appreciated five years ago:

\begin{tabular}{|c|r|r|r|r|}
\hline 1-Not important & 2-Slightly important & 3-Moderately important & 4-Important & 5-Very important \\
\hline \multicolumn{5}{|c|}{ 2.2. INSUFFICIENT SPECIALIZATION } \\
\hline My today's appreciation: \\
\hline 1-Not important & 2-Slightly important & 3-Moderately important & 4-Important & 5-Very important \\
\hline
\end{tabular}


How I appreciated five years ago:

\begin{tabular}{|c|c|c|c|c|}
\hline 1-Not important & 2-Slightly important & 3-Moderately important & 4-Important & 5-Very important \\
\hline \multicolumn{5}{|c|}{ 2.3. WORK INEXPERIENCE } \\
\hline \multicolumn{5}{|l|}{ My today's appreciation: } \\
\hline 1-Not important & 2-Slightly important & 3-Moderately important & 4-Important & 5-Very important \\
\hline \multicolumn{5}{|c|}{ How I appreciated five years ago: } \\
\hline 1-Not important & 2-Slightly important & 3-Moderately important & 4-Important & 5-Very important \\
\hline \multicolumn{5}{|c|}{ 2.4. OVERALL NEGATIVE WORKING CULTURE } \\
\hline \multicolumn{5}{|c|}{ My today's appreciation: } \\
\hline 1-Not important & 2-Slightly important & 3-Moderately important & 4-Important & 5-Very important \\
\hline \multicolumn{5}{|c|}{ How I appreciated five years ago: } \\
\hline 1-Not important & 2-Slightly important & 3-Moderately important & 4-Important & 5-Very important \\
\hline
\end{tabular}

3. What reasons do you think made you change your views over the last five years concerning the human resources you employ? In other words, what do you think are the new conditions and challenges for your business that contributed to changing your earlier understanding, and why?

Write your answer (up to one hundred words): 


\section{B. Training and Education}

\begin{tabular}{|c|c|c|c|c|}
\hline \multicolumn{5}{|c|}{$\begin{array}{l}\text { 4. To what extent would you want your firm's human resources to have more of the following training and } \\
\text { education forms? }\end{array}$} \\
\hline \multicolumn{5}{|c|}{ 4.1. MORE SOPHISTICATED TECHNICAL TRAINING } \\
\hline \multicolumn{5}{|c|}{ My today's appreciation: } \\
\hline 1-Not important & 2-Slightly important & 3-Moderately important & 4-Important & 5-Very important \\
\hline \multicolumn{5}{|c|}{ How I appreciated five years ago: } \\
\hline 1-Not important & 2-Slightly important & 3-Moderately important & 4-Important & 5-Very important \\
\hline
\end{tabular}

My today's appreciation:

\begin{tabular}{|l|l|l|l|l|}
\hline 1-Not important & 2-Slightly important & 3-Moderately important & 4-Important & 5-Very important \\
\hline
\end{tabular} How I appreciated five years ago:

\begin{tabular}{|l|l|l|l|l|} 
1-Not important & 2-Slightly important & 3-Moderately important & 4-Important & 5-Very important \\
\hline
\end{tabular}

\subsection{MORE TRAINING ON THE JOB}

My today's appreciation:

\begin{tabular}{|l|l|l|l|l|} 
1-Not important & 2-Slightly important & 3-Moderately important & 4-Important & 5-Very important
\end{tabular}

How I appreciated five years ago:

\begin{tabular}{l|l|l|l|l|} 
1-Not important & 2-Slightly important & 3-Moderately important & 4-Important & 5-Very important
\end{tabular}

\subsection{MORE SIGNIFICANT WORK EXPERIENCE REGARDLESS OF PREVIOUS TRAINING}

My today's appreciation:

\begin{tabular}{|l|l|l|l|l|} 
1-Not important & 2-Slightly important & 3-Moderately important & 4-Important & 5-Very important
\end{tabular} How I appreciated five years ago:

\begin{tabular}{|l|l|l|l|l|} 
1-Not important & 2-Slightly important & 3-Moderately important & 4-Important & 5-Very important
\end{tabular} 5. To what extent do you think it would be interesting to develop your business knowledge in the following?

\subsection{MANAGEMENT TECHNIQUES}

My today's appreciation:

\begin{tabular}{|l|l|l|l|l|} 
1-Not important & 2-Slightly important & 3-Moderately important & 4-Important & 5-Very important \\
\hline
\end{tabular}

How I appreciated five years ago:

\begin{tabular}{|l|l|l|l|l|}
\hline 1-Not important & 2-Slightly important & 3-Moderately important & 4-Important & 5-Very important \\
\hline
\end{tabular}

\subsection{SALES TECHNIQUES}

My today's appreciation:

\begin{tabular}{|l|l|l|l|l|} 
1-Not important & 2-Slightly important & 3-Moderately important & 4-Important & 5-Very important
\end{tabular} How I appreciated five years ago:

\begin{tabular}{|l|l|l|l|l|} 
1-Not important & 2-Slightly important & 3-Moderately important & 4-Important & 5-Very important
\end{tabular}

\subsection{CUSTOMER CARE}

My today's appreciation: 


\begin{tabular}{|c|c|c|c|c|}
\hline 1-Not important & 2-Slightly important & 3-Moderately important & 4-Important & 5-Very important \\
\hline \multicolumn{5}{|c|}{ How I appreciated five years ago: } \\
\hline 1-Not important & 2-Slightly important & 3-Moderately important & 4-Important & 5-Very important \\
\hline \multicolumn{5}{|c|}{ 5.4. BUSINESS PLANNING METHODS } \\
\hline \multicolumn{5}{|c|}{ My today's appreciation: } \\
\hline 1-Not important & 2-Slightly important & 3-Moderately important & 4-Important & 5-Very important \\
\hline \multicolumn{5}{|c|}{ How I appreciated five years ago: } \\
\hline 1-Not important & 2-Slightly important & 3-Moderately important & 4-Important & 5-Very important \\
\hline \multicolumn{5}{|c|}{$\begin{array}{l}\text { 6. Have you changed your understanding during the past five years about the importance of training your } \\
\text { human resources? }\end{array}$} \\
\hline \multicolumn{5}{|c|}{ Write your answer (up to one hundred words): } \\
\hline
\end{tabular}

\section{Copyrights}

Copyright for this article is retained by the author(s), with first publication rights granted to the journal.

This is an open-access article distributed under the terms and conditions of the Creative Commons Attribution license (http://creativecommons.org/licenses/by/4.0/). 